\title{
Interactive Impact of Biochar and Arbuscular Mycorrhizal on Root Morphology, Physiological Properties of Fenugreek (Trigonella foenum-graecum L.) and Soil Enzymatic Activities
}

\author{
Dilfuza Jabborova $\left.{ }^{1,2, *}{ }^{(}\right)$, Kannepalli Annapurna ${ }^{2, *}$, Ravish Choudhary $\left.{ }^{3}{ }^{(}\right)$, Subrata Nath Bhowmik ${ }^{2}$, \\ Said E. Desouky ${ }^{4}{ }^{(0)}$, Samy Selim ${ }^{5}{ }^{(D}$, Islam H. El Azab ${ }^{6}{ }^{(}$, Maha M. A. Hamada ${ }^{7}$, Nihal El Nahhas ${ }^{8}(\mathbb{D}$ \\ and Amr Elkelish ${ }^{9}$
}

check for updates

Citation: Jabborova, D.; Annapurna,

K.; Choudhary, R.; Bhowmik, S.N.; Desouky, S.E.; Selim, S.; Azab, I.H.E.; Hamada, M.M.A.; Nahhas, N.E.; Elkelish, A. Interactive Impact of Biochar and Arbuscular Mycorrhizal on Root Morphology, Physiological Properties of Fenugreek (Trigonella foenum-graecum L.) and Soil Enzymatic Activities. Agronomy 2021, 11, 2341. https://doi.org/10.3390/ agronomy11112341

Academic Editor: Lukas Trakal

Received: 24 October 2021

Accepted: 15 November 2021

Published: 19 November 2021

Publisher's Note: MDPI stays neutral with regard to jurisdictional claims in published maps and institutional affiliations.

Copyright: (c) 2021 by the authors. Licensee MDPI, Basel, Switzerland. This article is an open access article distributed under the terms and conditions of the Creative Commons Attribution (CC BY) license (https:/ / creativecommons.org/licenses/by/ $4.0 /)$.
1 Institute of Genetics and Plant Experimental Biology, Uzbekistan Academy of Sciences, Kibray, Tashkent 111208, Uzbekistan

2 Division of Microbiology, ICAR-Indian Agricultural Research Institute, Pusa, New Delhi 110012, India; subrata@iari.res.in

3 Division of Seed Science and Technology, ICAR-Indian Agricultural Research Institute, New Delhi 110012, India; ravianu1110@gmail.com

4 Department of Botany and Microbiology, Faculty of Science, Al-Azhar University, Nasr, Cairo 11884, Egypt; dr_saidesouky@yahoo.com

5 Department of Clinical Laboratory Sciences, College of Applied Medical Sciences, Jouf University, Sakaka 72341, Saudi Arabia; sabdulsalam@ju.edu.sa

6 Food Science \& Nutrition Department, College of Science, Taif University, P.O. Box 11099, Taif 21944, Saudi Arabia; i.helmy@tu.edu.sa

7 Department of Agronomy, Faculty of Agriculture, Ain Shams University, Cairo 11566, Egypt; Maha_hamada@agr.asu.edu.eg

8 Botany and Microbiology Department, Faculty of Science, Alexandria University, Alexandria 21515, Egypt; nihal.elnahhas@alexu.edu.eg

9 Botany Department, Faculty of Science, Suez Canal University, Ismailia 41522, Egypt; amr.elkelish@science.suez.edu.eg

* Correspondence: dilfuzajabborova@yahoo.com (D.J.); head_micro@iari.res.in (K.A.)

\begin{abstract}
Arbuscular mycorrhizal fungi (AMF) inoculation and biochar amendment has been reported to improve the growth of several crop plant; however, their role in stress amelioration individually as well as in combination has not been worked out. Limited information is available about the synergistic use of biochar and Arbuscular Mycorrhizal Fungi (AMF). Here, we investigated the synergistic effect of biochar and AMF on plant development, root architecture, the physiological performance of fenugreek (Trigonella foenum-graecum), and soil enzymatic activities. Biochar and AMF were shown to have a considerable effect on plant height, according to the data (53.3 and $66.6 \%$, respectively), leaf number ( 22.5 and $45.1 \%$ ), total root length (19.8 and $40.1 \%$ ), root volume (32.1 and $71.4 \%)$, chlorophyll a content (26.0 and $17.8 \%)$, chlorophyll b content (50.0 and $28.9 \%)$, total chlorophyll content (30.0 and $18.1 \%$ ), and carotenoid content (60.0 and $48.0 \%$ ) over the control treatment. There was a considerable increase in plant height when biochar and AMF were combined together by $80.9 \%$, total root length by $68.9 \%$, projected area by $48.7 \%$, root surface area by $34.4 \%$, root volume by $78.5 \%$, chlorophyll a content by $34.2 \%$, chlorophyll b content by $68.4 \%$, total chlorophyll content by $44.5 \%$, and carotenoid content by $84.0 \%$ compared to the control. Our results recommend that the combination of biochar and AMF is advantageous in fenugreek growth, microbial biomass, and soil enzyme activities.
\end{abstract}

Keywords: plant height; nodule number; root length; chlorophyll content; relative water content; microbial biomass

\section{Introduction}

Medicinal plants are sometimes used in both traditional medicine and modern medicine [1-5]. Fenugreek (Trigonella foenum-graecum L.), a medicinal crop, forage legume, 
and a traditional spice crop, belongs to the family Fabaceae [6]. The medicinal crop has been used traditionally in Indian Ayurvedic medicine, traditional Tibetan and Iranian medicine, Chinese medication, and modern medicine [7,8]. Seeds and leaves of fenugreek are useful in treating several diseases such as diabetes, cancer, head colds, influenza, constipation, bronchial complaints, asthma, emphysema, pneumonia, pleurisy, tuberculosis, sore throat, laryngitis, and fever [9-13]. Fenugreek seeds and leaves positively regulate blood sugar and blood cholesterol levels [14]. Seeds of fenugreek are a rich source of vitamins A, B1, and C, as well as carbohydrates (45-60\%), proteins (20-30\%), and fixed oils $(5-10 \%)$ (mainly trigonelline $(0.2-0.38 \%)$, choline $(0.5 \%)$, saponins $(0.6-1.7 \%)$, and volatile oils $(0.015 \%)$. They are also a source of gentianine and carpaine, the flavonoids apigenin, luteolin, orientin, quercetin, vitexin, and isovitexin, the free amino acids arginine, histidine and lysine, and calcium and iron [15].

Recent trends in agricultural focus on minimising organic manure and expansion in usage of biofertilizer $[16,17]$. In addition to increasing soil health, organic manures provide the most important nutrients and micronutrients [18-20]. Biochar is eco-friendly and helps plant growth and development, as well as improving the physical, chemical, and biological properties of the soil and increasing the yield of various crops under different conditions [16-24]. Zhang et al. [25] reported that the composition of biochar includes carbon, nitrogen, hydrogen, and lower nutrient elements, such as $\mathrm{K}, \mathrm{Ca}, \mathrm{Na}$, and $\mathrm{Mg}$. It plays an important role in soil nutrient availability, adsorption, and soil enzyme activity [26-29]. He et al. [30] indicated that biochar enhanced the absorption of nitrogen $(\mathrm{N})$, phosphorus $(\mathrm{P})$, and potassium $(\mathrm{K})$ by tomato. According to many studies, biochar treatment on its own has led to higher enzyme activity in soils with an acidic or alkaline $\mathrm{pH}$, for instance, alkaline phosphatase, alkaline phosphomonoesterase, phosphohydrolase, and lipase-esterase [31-34]. AMF is known to improve the soil $\mathrm{P}$ mobilization and availability. Improved activities are an indication of the stimulatory effect of biochar and AMF on the residential microbial population, many of which will possess plant growth promoting (PGP) traits. Enzyme activity is the cumulative effect of long-term microbial activity and activity of the viable population at sampling. The overall dehydrogenase activity (DHA) of a soil depends on the activities of various dehydrogenases, a fundamental part of the enzyme system of all living microorganisms, such as enzymes of the respiratory metabolism, the citrate cycle, and $\mathrm{N}$ metabolism [35]. Numerous papers have revealed that biochar enhances overall plant development from germination to yield [36-39]. Saxena et al. [21] observed that the germination rate was higher when biochar was applied compared to the control. Rice straw biochar significantly increased plant height, the number of bolls per plant, average boll weight, and yield in cotton when compared to control treatment [40]. In biochar treatment, significantly higher $\mathrm{Ca}$ and $\mathrm{Mg}$ content in maize leaf samples was observed compared to untreated control samples [32]. Zhaoxiang et al. [41] found that the application of biochar has the effect of increasing root and shoot biomass of Ribwort. Biochar's impact on plant photosynthesis, chlorophyll content, and transpiration rate has been well-documented in several reports $[29,34,42]$. Sarma et al. [38] found that adding biochar with okra significantly improved the photosynthetic rate.

The integral importance of soil life in agricultural sustainability, including plant symbiotic associations, is steadily increasingly being recognized $[16,17]$. One of the prominent players among these symbioses is mycorrhiza, the common symbiotic combination of fungi and plant roots $[43,44]$. Arbuscular mycorrhizal fungi (AMF) play a major role in improving plant growth, plant nutrition, and soil enzyme activities while also promoting microbial activity [43-46]. Ascorbate peroxidase, catalase, and other enzymes are enhanced in plants inoculated with AMF [47]. Numerous researches have demonstrated that AMF treatment enhances root system branching, plant growth, and crop yield. [48-50]. Yaseen et al. [51] and Shokri and Maadi [52] stated that the rhizosphere microflora consists primarily of AMF, particularly prominent in natural environments. Thus, they play a crucial role in ecosystem function through biogeochemical cycles. Najafi et al. [53] observed that plant growth-promoting bacteria and AMF 
co-inoculation might be useful for agriculture. Combined treatment with biochar and AMF has improved plant biometrics and soil enzyme activities. Using biochar with AMF has demonstrated the following: boosting plant growth, decreasing disease severity, and enhancing productivity. In maize, the application of biochar and AMF significantly improved phosphorus uptake [54]. Combined with $9 \%$ biochar, AMF significantly increased total root length and the number of very thin roots, fine roots, and thick roots in strawberry [55]. Plant biomass, leaf chlorophyll content and leaf nitrogen content in $P$. australis significantly increased by combined biochar and AMF treatment [56]. There is very little information about the interaction of biochar and AMF on fenugreek (Trigonella foenum-graecum). We aimed to test the following three hypotheses: (1) biochar and AMF can promote growth and root morphological traits of fenugreek; (2) biochar and AMF can improve physiological properties of fenugreek; (3) biochar and AMF can interact to enhance soil enzymatic activities and microbial biomass.

\section{Materials and Methods}

\subsection{Materials (Seed, AMF, Biochar, and Soil)}

The experiment was performed using field soil obtained from the Indian Agricultural Research Institute. The studied soil had the following agrochemical properties: $\mathrm{pH}-8.0$, electrical conductivity $0.45 \mathrm{ds} / \mathrm{m}$, soil organic carbon $0.41 \%$, nitrogen $167 \mathrm{~kg} / \mathrm{ha}$, phosphorus $40.3 \mathrm{~kg} / \mathrm{ha}$, potassium $788 \mathrm{~kg} / \mathrm{ha}$. The biochar with a particle size $>2 \mathrm{~mm}$ was purchased online (Amazon), and it was pyrolyzed at $400-500{ }^{\circ} \mathrm{C}$ from woody materials. From the Indian Agricultural Research Institute, the seed of fenugreek (Rajasthan Methi) and AMF were purchased.

\subsection{Experimental Design}

Fenugreek growth was examined using pot experiments in a green house at IARI's Division of Microbiology in New Delhi, India, to determine the effect of biochar and AFM. The entire experiment was conducted in a randomized block design with five repeats. In each replication, four plants have been taken for the mean). Biochar was applied at $\sim 16$ tons per hectar $(1 \% w / v)$ to ensure the better growing of AMF in the soil. The experimental design was as follows; control (soil without biochar), biochar alone, AFM alone, and biochar + AMF. We used a pot experiment, mixing the soil with nothing, 1.0\% biochar (or AMF). The experiment was carried out by introduction of AMF biofertilizer produced at IARI, Delhi, to the soil. The soil already may hold ineffective strains of native AMF. The AMF biofertilizer consists of 100 spores/g and $1200 \mathrm{IP} / \mathrm{g}$. The AMF biofertilizer was layered at a depth of $5 \mathrm{~cm}$ from the surface of soil, ensuring 10 spores for each seed. Seeds were cultivated in plastic pots $(20 \mathrm{~cm}$ diameter, $20 \mathrm{~cm}$ depth) containing $5.0 \mathrm{~kg}$ of soil. Each pot was watered once every 3 days. Soil temperature was maintained at $13-24{ }^{\circ} \mathrm{C}$ (day) $/ 4-14{ }^{\circ} \mathrm{C}$ (night). The pot experiments in a net house started on 14 December 2020 and ended on 23 January 2021. Harvest occurred at 40 days, at which point morphological traits were all measured.

\subsection{Measurement of Root Morphological Traits of Fenugreek}

The root system was analyzed by a scanning system (Expression 4990, Epson, Los Alamitos, CA, USA). The digital images of the root were investigated by Win RHIZO software (Québec, QC, Canada).

\subsection{Physiological Parameters Measurement}

The relative water content (RWC) was measured in accordance with Barrs and Weatherly [57]. Photosynthetic pigments were measured according to the Hiscox and Israelstam method [58]. 


\subsection{AMF Spores Soil Analysis}

AMF spores were extracted from the soil by the wet sieving method. The spores were calculated by a microscope in accordance with Dare et al. [59].

\subsection{Soil Microbial Biomass Analysis}

Microbial biomass was measured in accordance with Vance et al. [60]. The absorbance of samples was measured at $280 \mathrm{~nm}$.

\subsection{Soil Enzymes Analysis}

The alkaline phosphatase enzyme was analyzed according to Tabatabai and Bremner [61], while fluorescein diacetate hydrolytic was measured according to Green et al. [62]. Dehydrogenase enzyme activity was measured according to Casida et al. [63].

\subsection{Statistical Analyses}

One-way ANOVA was used to examine experimental data for multiple comparisons of HSD employing the Tukey test with StatView Software (SAS Institute, Cary, NC, USA, 1998). The significance of the effect of various treatments on plant growth parameters was determined by the magnitude of the $p$-value $(p<0.05<0.001)$.

\section{Results}

\subsection{Plant Growth Parameters}

The plant inoculated with AMF alone significantly improved the plant height by $53.3 \%$ in comparison to the control (Table 1), while the biochar alone significantly increased the plant height by $66.6 \%$, the leaf number by $45.1 \%$, and the nodule number by $35.9 \%$ as compared to control (Table 1). The combined application of biochar and AMF treatment significantly increased plant height by $80.9 \%$ over the control. The maximum leaf number was recorded and the combined treatment with biochar and AMF resulted in a 59.1\% increase with respect to the control. Combined application of biochar and AMF treatment showed a positive effect on branch and nodule numbers, with a significant increase in the number of branches $(35.8 \%)$ and nodule number $(60.3 \%)$ over control (Table 1$)$.

Table 1. Impact of biochar and AMF on plant growth parameters (plant height, leaf, branch and nodule numbers) of fenugreek.

\begin{tabular}{ccccc}
\hline Treatments & $\begin{array}{c}\text { Plant Height } \\
(\mathbf{c m})\end{array}$ & Leaf Number & $\begin{array}{c}\text { Branches } \\
\text { Number }\end{array}$ & $\begin{array}{c}\text { Nodule } \\
\text { Number }\end{array}$ \\
\hline Control & $15.00 \pm 0.95 \mathrm{c}$ & $31.00 \pm 1.00 \mathrm{~d}$ & $4.66 \pm 0.12 \mathrm{a}$ & $64.000 \pm 2.80 \mathrm{c}$ \\
\hline Biochar & $25.00 \pm 0.91 \mathrm{a}, \mathrm{b}$ & $45.00 \pm 1.02 \mathrm{~b}^{*}$ & $5.66 \pm 0.15 \mathrm{a}$ & $87.00 \pm 3.05 \mathrm{~b}$ \\
\hline AMF & $23.00 \pm 0.58 \mathrm{~b}$ & $38.00 \pm 1.96 \mathrm{c}$ & $5.00 \pm 0.12 \mathrm{a}$ & $82.33 \pm 3.24 \mathrm{~b}$ \\
\hline Biochar + AMF & $27.14 \pm 0.88 \mathrm{a}$ & $49.33 \pm 2.03 \mathrm{a},{ }^{* *}$ & $6.33 \pm 0.26 \mathrm{a}$ & $102.67 \pm 4.40 \mathrm{a}$ \\
\hline HSD $\leq 0.05$ & 2.44 & 2.28 & 1.84 & 5.01 \\
\hline
\end{tabular}

Data are means of five replicates $(n=5)$, for each parameter, ${ }^{*}$ asterisk differed significantly at $p<0.05^{*}, p<0.01^{* *}$ The mean values \pm SD followed by a different letter are significantly different according to Tukey's HSD range test at $p \leq 0.05$.

Data regarding the root fresh weight showed that AMF treatment significantly increased the root fresh weight by $54.2 \%$ compared with the control (Table 2). Treatment of biochar alone significantly increased the root fresh weight by $71.4 \%$ and the root dry weight by $25.0 \%$ compared with the control. However, the combined application of biochar and AMF showed a higher positive effect on root fresh weight $(82.8 \%)$ and dry weight $(37.5 \%)$ over control compared to a singular treatment with either component. There was also an improvement in shoot fresh weight $(47.6 \%)$ and shoot dry weight $(49.2 \%)$. 
Table 2. Impact of biochar and AMF on fresh and dry weights of root and shoot of fenugreek.

\begin{tabular}{ccccc}
\hline Treatments & $\begin{array}{c}\text { Root Fresh } \\
\text { Weight } \mathbf{( g )}\end{array}$ & $\begin{array}{c}\text { Shoot Fresh } \\
\text { Weight (g) }\end{array}$ & $\begin{array}{c}\text { Root Dry } \\
\text { Weight (g) }\end{array}$ & $\begin{array}{c}\text { Shoot Dry } \\
\text { Weight (g) }\end{array}$ \\
\hline Control & $0.35 \pm 0.01 \mathrm{~d}$ & $4.68 \pm 0.09 \mathrm{~d}$ & $0.08 \pm 0.01 \mathrm{~b}$ & $0.65 \pm 0.01 \mathrm{~d}$ \\
\hline Biochar & $0.60 \pm 0.01 \mathrm{~b}$ & $5.36 \pm 0.12 \mathrm{~b}$ & $0.10 \pm 0.01 \mathrm{ab}$ & $0.77 \pm 0.01 \mathrm{~b}$ \\
\hline AMF & $0.54 \pm 0.01 \mathrm{c}$ & $5.11 \pm 0.14 \mathrm{c}$ & $0.09 \pm 0.01 \mathrm{ab}$ & $0.72 \pm 0.01 \mathrm{c}$ \\
\hline Biochar + AMF & $0.64 \pm 0.01 \mathrm{a}$ & $6.91 \pm 0.20 \mathrm{a}$ & $0.11 \pm 0.01 \mathrm{a}$ & $0.97 \pm 0.01 \mathrm{a}$ \\
\hline HSD $\leq 0.05$ & 0.0261 & 0.1408 & 0.0213 & 0.0483 \\
\hline
\end{tabular}

Data are means of five replicates $(n=5)$, for each parameter, the mean values \pm SD followed by a different letter are significantly different according to Tukey's HSD range test at $p \leq 0.05$.

\subsection{Root Morphological Traits}

Examination of root morphological traits revealed an increase in the total root length, root surface area, projected area, root diameter, and root volume in biochar treatment (Table 1). Biochar significantly increased the total root length $40.1 \%$, projected area $22.4 \%$, root surface area $(23.6 \%)$, root volume $(71.4 \%)$, and root diameter $(20.3 \%)$ in comparison to the control, while plants inoculated with AMF gradually enhanced the total root length $(19.8 \%)$ and root volume (32.1\%). However, the combination of biochar with AMF increased the total root length $(68.9 \%)$, projected area $(48.7 \%)$, root surface area $(34.4 \%)$, root volume $(34.4 \%)$, and root diameter $(31.0 \%)$ over control (Table 3$)$.

Table 3. Impact of biochar and AMF on root morphological traits of fenugreek.

\begin{tabular}{|c|c|c|c|c|c|}
\hline Treatments & $\begin{array}{l}\text { Total Root } \\
\text { Length }(\mathrm{cm})\end{array}$ & $\begin{array}{l}\text { Projected Area } \\
\qquad\left(\mathrm{cm}^{2}\right)\end{array}$ & $\begin{array}{l}\text { Root Surface } \\
\text { Area }\left(\mathrm{cm}^{2}\right)\end{array}$ & $\begin{array}{l}\text { Root Volume } \\
\qquad\left(\mathrm{cm}^{3}\right)\end{array}$ & $\begin{array}{l}\text { Root Diameter } \\
\text { (mm) }\end{array}$ \\
\hline Control & $45.25 \pm 2.01 \mathrm{~d}$ & $5.80 \pm 0.11 \mathrm{~d}$ & $7.25 \pm 0.20 \mathrm{~d}$ & $0.28 \pm 0.01 \mathrm{~d}$ & $0.64 \pm 0.01 \mathrm{~d}$ \\
\hline Biochar & $63.34 \pm 2.70 b$ & $7.10 \pm 0.20 \mathrm{~b}$ & $8.90 \pm 0.38 b$ & $0.48 \pm 0.01 \mathrm{~b}$ & $0.77 \pm 0.01 \mathrm{~b}$ \\
\hline AMF & $54.16 \pm 1.26 c$ & $6.40 \pm 0.15 c$ & $8.10 \pm 0.29 c$ & $0.37 \pm 0.01 \mathrm{c}$ & $0.71 \pm 0.01 \mathrm{c}$ \\
\hline Biochar + AMF & $76.37 \pm 3.10 \mathrm{a}$ & $8.63 \pm 0.29 \mathrm{a}$ & $9.68 \pm 0.36 \mathrm{a}$ & $0.50 \pm 0.01 \mathrm{a}$ & $0.84 \pm 0.01 \mathrm{a}$ \\
\hline $\mathrm{HSD} \leq 0.05$ & 4.81 & 0.2387 & 0.3038 & 0.0213 & 0.025 \\
\hline
\end{tabular}

Data are means of five replicates $(n=5)$, for each parameter, the mean values \pm SD followed by a different letter are significantly different according to Tukey's HSD range test at $p \leq 0.05$.

\subsection{Physiological Properties of Fenugreek}

The effects of biochar and AMF application alone and in combination on the physiological properties of fenugreek are provided in Figures 1 and 2. Data in Figure 1 show that sole application of biochar significantly increased leaf contents of chlorophyll a by $17.8 \%$, chlorophyll b by $28.9 \%$, total chlorophyll by $18.1 \%$, and carotenoid by $48.0 \%$. As compared to the control, the AMF alone documented a $26.0 \%$ increase in chlorophyll a, $50 \%$ increase in chlorophyll b, 30\% increase in total chlorophyll, and $60.0 \%$ increase in carotenoid content. The combination of biochar and AMF significantly enhanced the chlorophyll a, chlorophyll b, total chlorophyll content and carotenoid content by $34.2 \%, 68.4 \%, 44.5 \%$ and $84.0 \%$, respectively (Figure 1).

\subsection{AMF Spores Number, Microbial Biomass and Soil Enzymes Activity}

Biochar and AMF treatments alone, as shown in Figure 2, increased leaf water content, although not significantly. The biochar-AMF treatment had the greatest leaf relative water content compared to the control.

The amount of AMF spores that were treated with biochar was 52.3 percent higher than in the control group (Figure 3). It was shown that AMF alone and in combination with biochar raised the spore count of AMF from $111 \%$ to $161 \%$. 


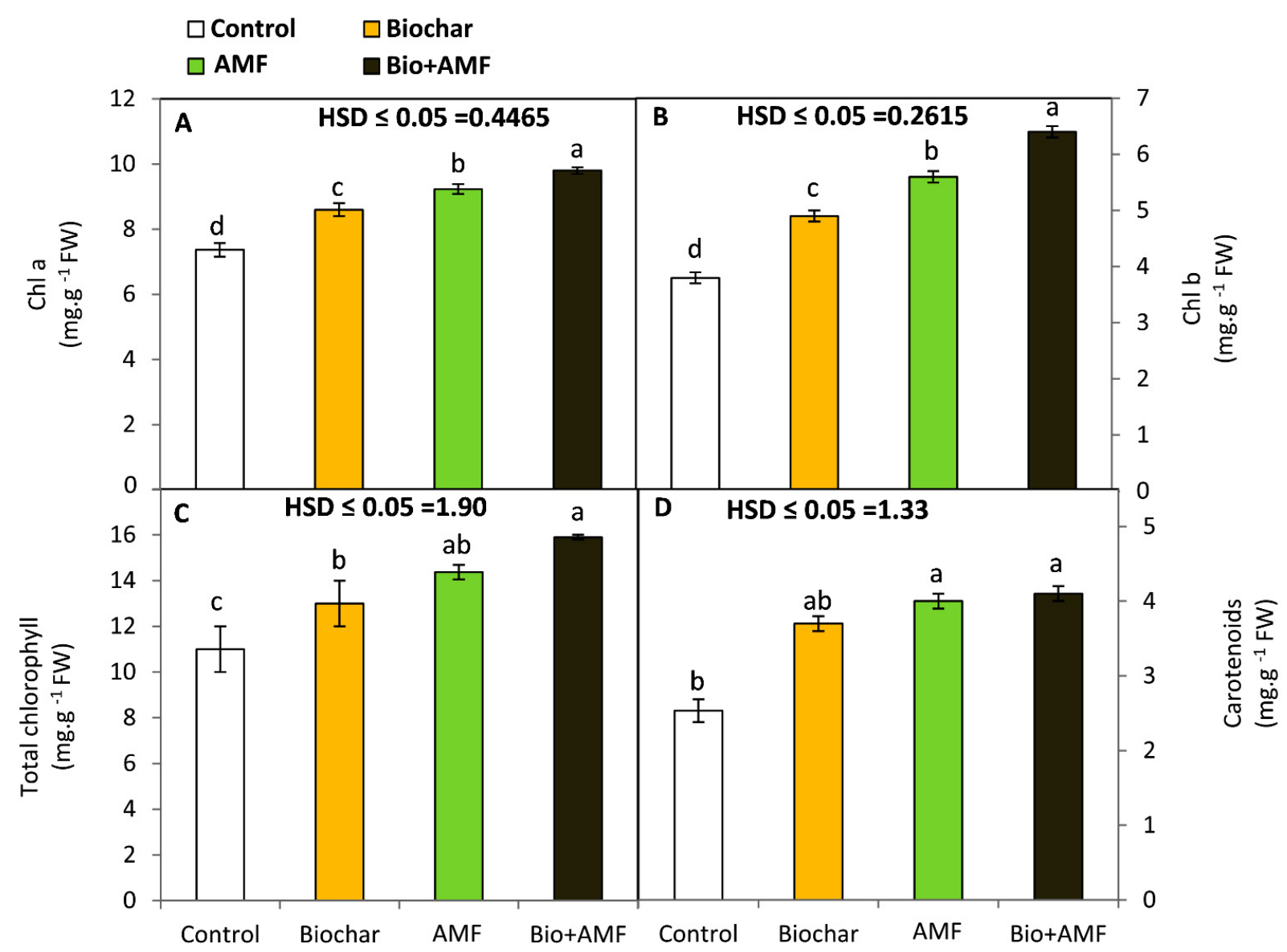

Figure 1. Impact of biochar and AMF on the photosynthetic pigments of fenugreek leaf. (A) Chlorophyll a, (B) Chlorophyll b, (C) Total Chlorophyll, (D) Carotenoid's content. Data are means of five replicates $(n=5)$, for each parameter, the mean values \pm SD followed by a different letter are significantly different according to Tukey's HSD range test at $p \leq 0.05$.

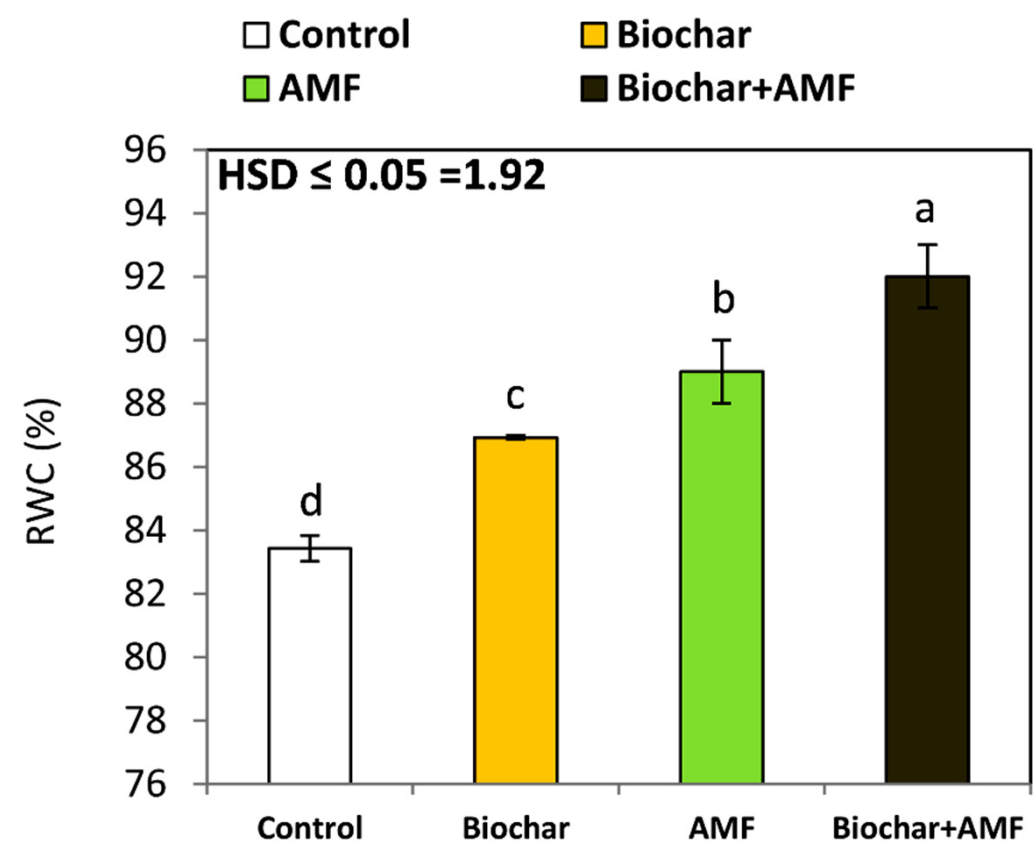

Figure 2. Impact of biochar and AMF on the relative water content of fenugreek leaf. Data are means of five replicates $(n=5)$, for each parameter, the mean values \pm SD followed by a different letter are significantly different according to Tukey's HSD range test at $p \leq 0.05$. 


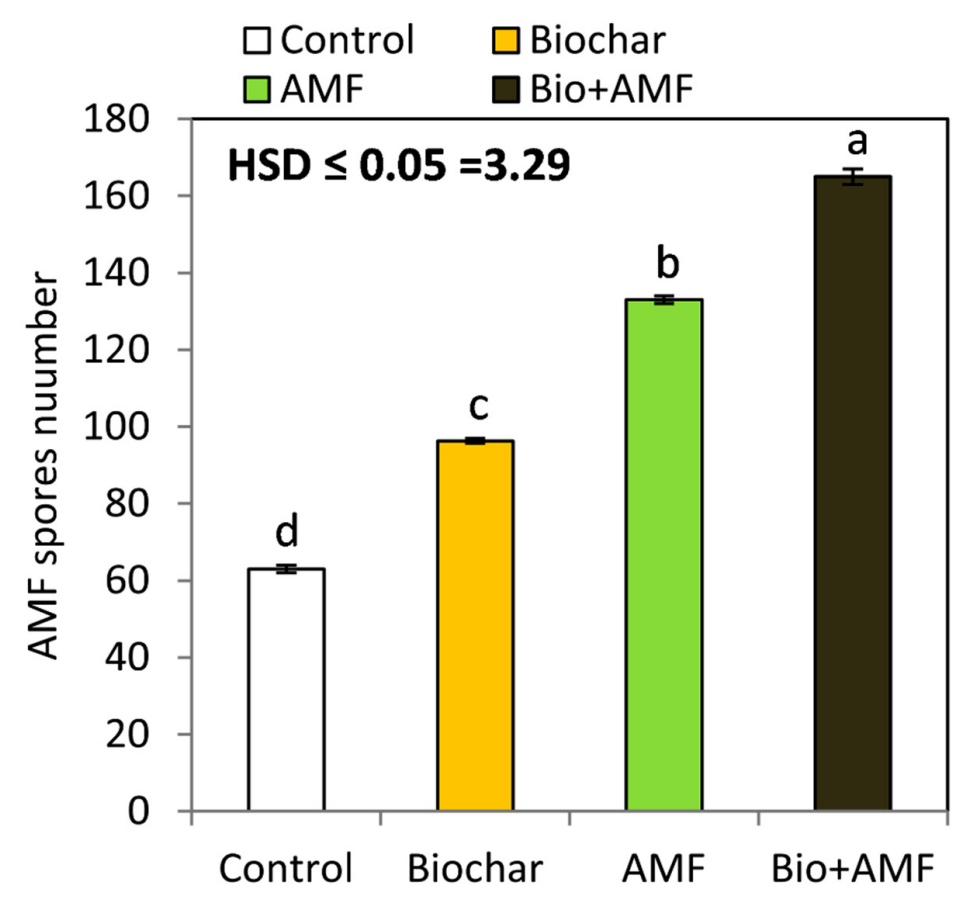

Figure 3. Impact of biochar and AMF on the AMF spores in soil. Data are means of five replicates $(n=5)$, and for each parameter, the mean values \pm SD followed by a different letter are significantly different according to Tukey's HSD range test at $p \leq 0.05$.

Figure 4 shows that biochar and AMF alone enhanced soil microbial biomass relative to the control. The microbial biomass increased by $44.4 \%$ and $54.6 \%$, respectively, in biochar and AMF treatments over the control. The maximum increase over the control in microbial biomass $(62.9 \%)$ was achieved in the treatment of biochar with AMF.

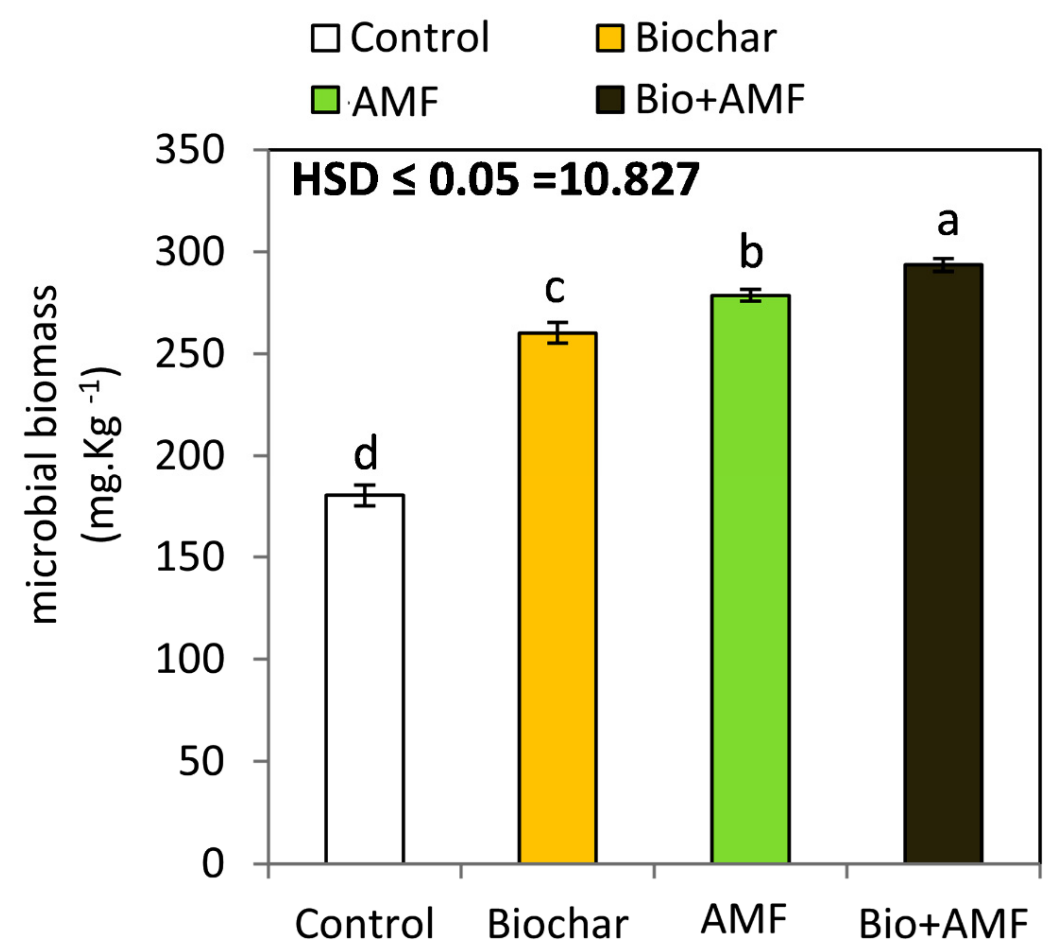

Figure 4. Impact of biochar and AMF on the microbial biomass in soil. Data are means of five replicates $(n=5)$, and for each parameter, the mean values \pm SD followed by a different letter are significantly different according to Tukey's HSD range test at $p \leq 0.05$. 
In the present study, the alkaline phosphatase activity under either biochar or AMF treatments was enhanced by $25.4 \%$ and $43.6 \%$, respectively, over the control (Table 4 ). The combined effect of biochar and AMF increased the alkaline phosphatase by $55.8 \%$. The biochar and AMF treatments individually documented a significant increase in dehydrogenase activity by $21.5 \%$ and $41.7 \%$, respectively, over control. However, dual application of biochar and AMF was more effective in enhancing the dehydrogenase activity $(61.1 \%)$ compared to other treatments. Biochar alone gradually increased fluorescein diacetate activity in comparison with the control. The fluorescein diacetate activity increased by $34.6 \%$ (biochar) and 57.0\% (AMF) treatments compared to the control. Treatment with biochar combined with AMF resulted in a greater increase in the activities of fluorescein diacetate activity $(77.4 \%)$ compared to all treatments.

Table 4. Impact of biochar and AMF on soil enzymes activities.

\begin{tabular}{cccc}
\hline Treatments & $\begin{array}{c}\text { Alkaline Phosphatase } \\
\left(\boldsymbol{\mu} \mathbf{g ~}^{-\mathbf{1}} \mathbf{h}^{-\mathbf{1}}\right)\end{array}$ & $\begin{array}{c}\text { Dehydrogenase } \\
\text { Activity }\left(\boldsymbol{\mu g} \mathbf{g}^{-\mathbf{1}} \mathbf{h}^{-\mathbf{1}}\right)\end{array}$ & $\begin{array}{c}\text { Fluorescein Diacetate } \\
\text { Activity }\left(\boldsymbol{\mu} \mathbf{g ~ g}^{-\mathbf{1}} \mathbf{h}^{-\mathbf{1}}\right)\end{array}$ \\
\hline Control & $76.1 \pm 3.03 \mathrm{~d}$ & $55.3 \pm 1.50 \mathrm{~d}$ & $50.0 \pm 1.09 \mathrm{~d}$ \\
\hline Biochar & $95.5 \pm 4.10 \mathrm{c}$ & $67.2 \pm 2.42 \mathrm{c}$ & $67.3 \pm 2.65 \mathrm{c}$ \\
\hline AMF & $109.3 \pm 4.21 \mathrm{~b}$ & $78.4 \pm 3.06 \mathrm{~b}$ & $78.5 \pm 3.13 \mathrm{~b}$ \\
\hline Biochar + AMF & $118.6 \pm 5.03 \mathrm{a}$ & $89.1 \pm 3.12 \mathrm{a}$ & $88.7 \pm 4.01 \mathrm{a}$ \\
\hline HSD $\leq 0.05$ & 3.34 & 4.79 & 5.15 \\
\hline
\end{tabular}

Data are means of five replicates $(n=5)$, for each parameter, the mean values \pm SD followed by a different letter are significantly different according to Tukey's HSD range test at $p \leq 0.05$.

\section{Discussion}

\subsection{Impact of Biochar and AMF on Fenugreek Plant Growth Parameters}

Biochar application has revealed a wide range of benefits to plant growth through plant germination and development. In general, biochar treatment increased plant height by $66.6 \%$, leaf number by $45.1 \%$, and nodule number by $35.9 \%$ over control treatment (Table 1). Several researchers have reported that biochar application improves plant growth, development, and yield in different plants [29,30,32,34,39]. Similarly, Saxena et al. [27] found that root length, shoot length, and root biomass were positively impacted by biochar treatment, also seen by Zheng et al. [64], where biochar treatment increased the plant biomass of Chinese cabbage. This result is in line with that of the Gonzaga et al. study [65], who observed an increase in maize (Zea mays L.) plant growth when treated with coconut husk biochar compared to the control without any biochar. Qayyum et al. [40] observed that the rice straw biochar application significantly increased the plant height by $22.47 \%$, the number of bolls per plant by $13.75 \%$, average boll weight by $36.22 \%$, and seed cotton yield by $14.48 \%$ compared with the control. Data regarding biochar alone treatment significantly increased the root fresh weight and the root dry weight by $71.4 \%$ and $25.0 \%$ over the control, respectively (Table 2). Similarly, Bopp et al. [66] reported that alkaline biochar significantly increased root growth, development, and root biomass. Trupiano et al. [34] found that morphological traits were enhanced in biochar applications (Figure 5). All reports discussed the beneficial effect that biochar is believed to help boost soil fertility by increasing soil acidity $[27,30,32,34]$.

AMF are beneficial symbiotic fungi improving plant growth, development, and plant nutrient uptake in various crops. Data regarding the AMF treatment show a significant increase in plant height $(53.3 \%)$, nodule number $(28.5 \%)$, and root fresh weight $(54.2 \%)$ in comparison to untreated plants (Tables 1 and 2). Several researchers report that AMF improved plant growth parameters of different plants [67-73]. Similar results were indicated by Fougnies et al. [74], where AMF increased plant growth, and nodulation of Pterocarpus officinalis Sharma and Kayang [75] reported that inoculating with AMF noticeably increased plant growth parameters such as number of leaves, leaf area, plant height, shoot length, root length, and root and shoot weight of tea (Camellia sinensis (L.)). They all refer to this 
effect through improving water content and intercellular $\mathrm{CO}_{2}, \mathrm{P}$, and $\mathrm{N}$ contents [67-73]. The AMF can contribute to the increase in root dry matter in compacted soils, allowing decompression by improving the physical, chemical, and biological conditions of the soil, increasing the nutrient cycle and the efficiency of correctives and fertilizers [70-73].

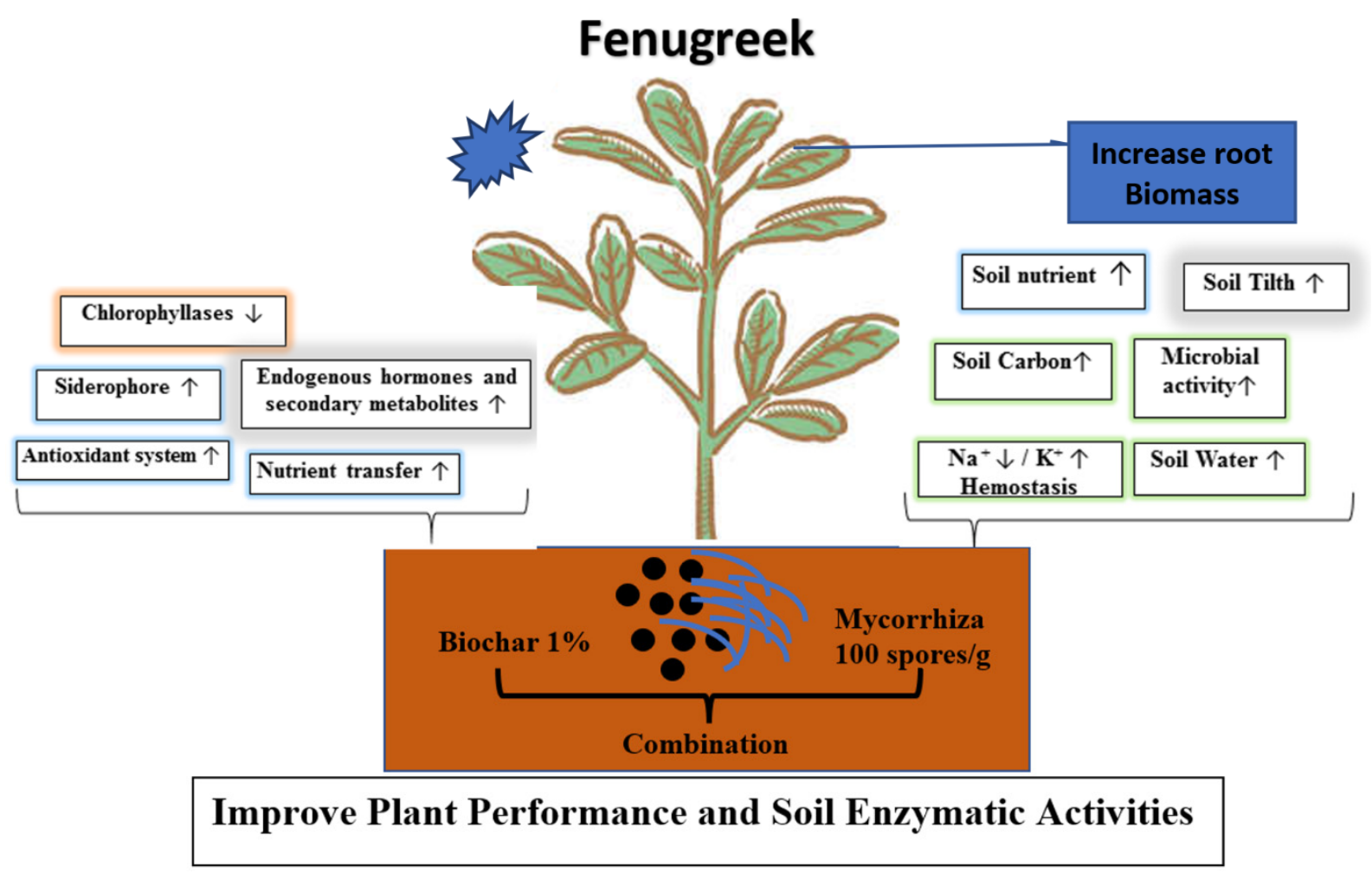

Figure 5. Summary of the mechanism of action for the joint impact of Biochar and AMF on plant development and soil enzymatic activity in the Fenugreek.

The application of biochar in conjunction with AMF treatment had a beneficial effect on plant height, leaf number, branches number, nodule number, and shoot/ root fresh and dry weight as compared to control (Tables 1 and 2). G. etunicatum and G. margarita were shown to have considerably increased height, diameter, shoot dry weight, and root dry weight relative to the control plants when both biochar and AMF were used [76]. The development of spinach, okra, and maize showed significance in the growth performance after the treatment with biochar and AMF $[28,29,77]$. The beneficial effect of the combined treatment starts from the biochar because the biochar trigger and enhance the AMF colonization. Therefore, the positive effect of the AMF is being doubled to three or four times due to the flourishing of the AMF and the development to the maximum limit under the best growth conditions. At the same time, the AMF synergistic effect with biochar by reaching the maximum soil conditioning to supply the best and optimum media for plant growth.

\subsection{Impact of Biochar and AMF on Root Morphological Traits of Fenugreek}

Root morphological characteristics were enhanced by biochar treatment compared to the control (Table 3). Numerous studies have shown that the addition of biochar to the soil improves plant root development [77-80]. Similar results were observed by Zheng et al. [64], where biochar application enhanced the root biomass and root system of Brassica chinensis L. (Chinese cabbage). Li and Cai [77] confirmed that biochar addition significantly improved root morphology. Trupiano et al. [34] also reported that the addition of biochar significantly improved plant root growth. This finding confirms earlier studies by Butnan et al. [81], who studied treatments of 1,2, and $4 \%$ biochar application and their effect on improving maize dry weight and root length over the control treatment. At $1 \%$, rice husk 
biochar and woodchip biochar significantly enhanced the root volume and root length [77]. The addition of biochar improved the taproot length, the root volume, and the total root absorption area in tobacco [82,83] (Figure 5). It is not surprising that this result occurs because the biochar application increases plant growth and increases the demand for nutrients and water. Due to this, biochar is an excellent tool to fix nutrient deficiencies by absorbing nutrients, notably inorganic $\mathrm{N}[64,77]$.

AMF treatment increased root length, projected area, root diameter, and root volume in comparison to the control group. A similar positive effect was reported in tomato (Lycopersicon esculatum) seedlings, where AMF treatment enhanced the number of root tips and total root length [84]. The AMF inoculation enhanced root hair length and density. [85]. AMF inoculation had positive effects on the root growth of carrot and sorghum as reported by Kim et al. [86] when compared to uninoculated plants. It has been demonstrated by Budi and Setyaningsih. [76] that AMF treatment of the chinaberry significantly increased the diameter and length of both shoot and root. A study carried out by Singh et al. [68] indicates that inoculation of AMF enhances root growth, and AMF inoculation alone significantly changes the morphology of the roots [87]. Similarly, AMF significantly increased chickpea root length [88]. AMF can reduce root injury stress by altering root shape [89]. Padmavathi et al. [90] observed that AMF inoculation improved root length over the control.

As shown in Table 3, biochar and AMF significantly enhanced root system parameters, such as the total root length $(68.9 \%)$, projected area $(48.7 \%)$, root surface area $(34.4 \%)$, root volume $(78.5 \%)$ and root diameter $(31.0 \%)$ as compared to the control treatment. Similar results were confirmed by Zhang et al. [83], where the combination of AMF and biochar, in addition to the root architecture, is also important in a plant's ability to utilize subterranean water and nutrients. This supports earlier findings by Hashem et al. [88], who reported that biochar in conjunction with AMF significantly enhances the length of chickpea root.

\subsection{Impact of Biochar and AMF on Fenugreek Physiological Properties}

The results presented in Figures 1 and 2 show that biochar treatment alone had a positive impact on fenugreek physiological parameters. Data in Figure 1 revealed that biochar treatment significantly increased chlorophyll a content by $17.8 \%$, the chlorophyll b content by $28.9 \%$, the total chlorophyll content by $18.1 \%$, and carotenoid content by $48.0 \%$ over the control. Biochar application has been shown to boost plant photosynthesis, chlorophyll content, and transpiration rate in a variety of plants, and this study's findings are consistent with this earlier research [29,34,42,91]. Hashem et al. [88] found that biochar application enhanced the total photosynthetic pigments. Biochar application also significantly increased the photosynthetic rate by $27 \%$ and chlorophyll concentration by $16 \%$ compared to the control [92]. Similarly, Sarma et al. [38] found a strong positive effect of biochar amendment in the rate of photosynthesis in okra. Biochar is well recognized to significantly enhance the water and nutrient availability to plant roots, resulting in increased pigment synthetase and assimilation in plant leaves [29,34,42,91].

In Figure 5, the AMF treatment significantly improved the photosynthetic pigments. Our results agree with previous research by Hashem et al. [88], where total photosynthetic and carotenoid pigments improved in the presence of AMF, as well as earlier studies by Dell'Amico et al. [93] and Ren et al. [94], where AMF improved leaf area, stomatal conductance, and photosynthetic activity. In addition, AMF inoculation increases the chlorophyll content and the photosynthetic rate of maize by Li and Cai [77]. Padmavathi et al. [90] reported that AMF-inoculated Rhizophagus irregularis had improved chlorophyll content and reduced proline concentration in tomatos (Lycopersicon esculatum) and bell peppers (Capsicum annuum). The researchers confirmed that AMF greatly increased antioxidant enzyme activity as well as net photosynthesis rate (Figure 5).

In the present investigation, the dual impact of biochar and AMF showed the greatest effect over all the other treatments on physiological parameters such as chlorophyll a content, chlorophyll b content, total chlorophyll content, carotenoid content, and relative water content (Figures 1 and 2). Dual inoculation significantly increased photosynthetic 
pigments, and relative leaf water content (Figures 1 and 2). These findings confirmed with the research of Hashem et al. [88]. As shown in Figure 5, AMF and biochar promote siderophore formation, nitrogen fixation, and boost nutrient absorption and availability. Furthermore, they cause the production of endogenous phytohormones and antioxidants to be stimulated [89-93].

\subsection{AMF Microbial Biomass, Spores Number and Soil Enzymes Activity}

Supplementation of biochar helps improve the number of AMF spores, microbial biomass, and enzyme activities such as alkaline phosphatase, dehydrogenase, and fluorescein diacetate. Similar to previous work [26,88], based on the findings of this investigation, biochar improved the number of AMF spores by $52.3 \%$ (Figure 3), microbial biomass by $44.4 \%$ (Figure 4 ), alkaline phosphatase by $25.4 \%$, dehydrogenase by $21.5 \%$, and fluorescein diacetate activities by $34.6 \%$ in soil (Table 4 ). Biochar treatment has been demonstrated in several studies to increase AMF colonization rates [95-97], and several studies have shown that biochar significantly enhances esterase, lipase-esterase, trypsin, chymotrypsin, phosphohydrolase, and protease enzyme activities [33,34,98]. Similar work has shown that maize biochar improved soil enzyme activity [99], biochar application improved the activities of protease, acid, and alkaline phosphatase in soil [22], biochar application significantly increased urease activity by $40 \%$, invertase activity by $9 \%$ and phosphatase activity by $46 \%$ at the highest biochar treatment rate $\left(12 \mathrm{t} \mathrm{ha}^{-1}\right)$ [100], and that biochar application results in enzyme activity in soil. [39,101]. Gunal et al. [102] reported that 2\% biochar treatment enhanced $\beta$-glucosidase activity in sandy loam soil. Biochar application increased microbial biomass carbon (MBC) content and phosphatase activity [103].

In the present study, AMF alone significantly enhanced soil numbers of AMF spores by $111.0 \%$ (Figure 3), microbial biomass by $54.6 \%$ (Figure 4 ), alkaline phosphatase by $43.6 \%$, dehydrogenase by $41.7 \%$, and fluorescein diacetate activities by $57.0 \%$ (Table 4 ). Similar results were observed by Li and Cai [77] and Ziheng et al. [104], where AMF inoculation improved soil microbial biomass and increased the enzyme activity in soil. These results are similar to previous work that showed that the combination of AMF and biochar treatment boosted soil microbial activity in the corn root and increased the amount of AMF spores in chickpea $[77,88]$.

\section{Conclusions}

While treatment with only biochar or AMF alone improves fenugreek growth performance and physiological parameters. Combined biochar and AMF significantly enhanced microbial biomass, AMF spore numbers, and soil enzyme activities. This is the first investigation to report the effect of biochar and AMF on promoting fenugreek growth, root morphological traits, physiological parameters, and soil enzyme activities in non-fertile soils. These findings imply that a combination of biochar and AMF can enhance fenugreek growth, total chlorophyll content, carotenoid content, relative water content, soil microbial biomass, and enzyme activity. In the future, we plan to investigate the interactive effect of biochar and AMF on the plant growth and yield of fenugreek (Trigonella foenum-graecum) in field conditions.

Author Contributions: All the authors collaborated in the experiments described in this article. Conceptulation D.J., K.A., R.C., S.N.B. Data curation D.J., S.S., I.H.E.A., M.M.A.H., N.E.N., A.E.; writingoriginal draft preparation, D.J.; writing-review and editing, D.J., K.A., R.C., S.N.B., S.E.D., S.S., I.H.E.A., M.M.A.H., N.E.N., A.E.; software, D.J., K.A., R.C., S.N.B., S.E.D., S.S., I.H.E.A., M.M.A.H., N.E.N., A.E.; visualization, D.J., K.A., R.C., S.N.B., S.E.D., S.S., I.H.E.A., M.M.A.H., N.E.N., A.E.; funding I.H.E.A., M.M.A.H., N.E.N. All authors have read and agreed to the published version of the manuscript.

Funding: The research visit was financed by the Department of Biotechnology, Government of India (DBT), and TWAS.

Institutional Review Board Statement: Not applicable. 
Informed Consent Statement: Not applicable.

Data Availability Statement: Not applicable.

Acknowledgments: The authors extend their appreciation to the Deanship of Scientific Research at Taif University for funding this work through Researchers Supporting Project number (TURSP-2020/27), Taif University, Taif, Saudi Arabia. We thank our colleagues at the Division of Microbiology, ICARIndian Agricultural Research Institute, New Delhi, India, for providing necessary support of laboratory and nethouse facilities.

Conflicts of Interest: The authors declare no conflict of interest.

\section{References}

1. Egamberdieva, D.; Jabborova, D. Medicinal Plants of Uzbekistan and Their Traditional Uses. In Vegetation of Central Asia and Environs; Egamberdieva, D., Öztürk, M., Eds.; Springer Nature Switzerland AG: Cham, Switzerland, 2018; pp. $211-237$.

2. Jabborova, D.; Davranov, K.; Egamberdieva, D. Antibacterial, Antifungal, and Antiviral Properties of Medicinal Plants. In Medically Important Plant Biomes: Source of Secondary Metabolites; Egamberdieva, D., Tiezzi, A., Eds.; Springer Nature: Singapore, 2019; pp. 51-65.

3. Jabborova, D.; Annapurna, K.; Fayzullaeva, M.; Sulaymonov, K.; Kadirova, D.; Jabbarov, Z.; Sayyed, R.Z. Isolation and characterization of endophytic bacteria from ginger (Zingiber officinale Rosc.). Ann. Phytomedicine 2020, 9, 116-121. [CrossRef]

4. Mamarasulov, B.; Davranov, K.; Jabborova, D. Phytochemical, pharmacological, and biological properties of Ajugatur kestanica (Rgl.) Brig (Lamiaceae). Ann. Phytomedicine 2020, 9, 44-57.

5. Jabborova, D.; Enakiev, Y.; Sulaymanov, K.; Kadirova, D.; Ali, A.; Annapurna, K. Plant growth-promoting bacteria Bacillus subtilis promote growth and physiological parameters of Zingiber officinale Roscoe. Plant Sci. Today 2021, 8, 66-71. [CrossRef]

6. Gaber, A.; Alsanie, W.F.; Kumar, D.N.; Refat, M.S.; Saied, E.M. Novel Papaverine Metal Complexes with Potential Anticancer Activities. Molecules 2020, 25, 5447. [CrossRef]

7. Duke, A.J. Handbook of Legumes of World Economic Importance; Plemus Press: New York, NY, USA; London, UK, 1986 ; p. 345.

8. Sharar, M.; Saied, E.M.; Rodriguez, M.C.; Arenz, C.; Montes-Bayón, M.; Linscheid, M.W. Elemental Labelling and Mass Spectrometry for the Specific Detection of Sulfenic Acid Groups in Model Peptides: A Proof of Concept. Anal. Bioanal. Chem. 2017, 409, 2015-2027. [CrossRef]

9. Sharma, R.D.; Raghuram, T.C.; Rao, N.S. Effect of fenugreek seeds on blood glucose and serum lipids in type I diabetes. Eur. J. Clin. Nutr. 1990, 44, 301-306. [PubMed]

10. Ethan, B.; Grace, K.; Michael, S. Therapeutic applications of fenugreek. Altern. Med. Rev. 2003, 8, $20-27$.

11. Gaber, A.; Refat, M.S.; Belal, A.A.M.; El-Deen, I.M.; Hassan, N.; Zakaria, R.; Alhomrani, M.; Alamri, A.S.; Alsanie, W.F.; Saied, E.M. New Mononuclear and Binuclear Cu(II), Co(II), Ni(II), and Zn(II) Thiosemicarbazone Complexes with Potential Biological Activity: Antimicrobial and Molecular Docking Study. Molecules 2021, 26, 2288. [CrossRef]

12. Ibrahim, M.F.M.; Ibrahim, H.A.; Abd El-Gawad, H.G. Folic Acid as a Protective Agent in Snap Bean Plants under Water Deficit Conditions. J. Hortic. Sci. 2021, 96, 94-109. [CrossRef]

13. Hasan, M.M.; Rahman, M.A.; Skalicky, M.; Alabdallah, N.M.; Waseem, M.; Jahan, M.S.; Ahammed, G.J.; El-Mogy, M.M.; El-Yazied, A.A.; Ibrahim, M.F.M.; et al. Ozone Induced Stomatal Regulations, MAPK and Phytohormone Signaling in Plants. Int. J. Mol. Sci. 2021, 22, 6304. [CrossRef] [PubMed]

14. Acharya, S.; Srichamroen, A.; Basu, S.; Ooraikul, B.; Basu, T. Improvement in the nutraceutical properties of fenugreek (Trigonella foenum-graecum L.). Songklanakarin J. Sci. Technol. 2006, 28, 1-9.

15. Abd El-Gawad, H.G.; Mukherjee, S.; Farag, R.; Abd Elbar, O.H.; Hikal, M.; Abou El-Yazied, A.; Abd Elhady, S.A.; Helal, N.; ElKelish, A.; El Nahhas, N.; et al. Exogenous $\gamma$-Aminobutyric Acid (GABA)-Induced Signaling Events and Field Performance Associated with Mitigation of Drought Stress in Phaseolus Vulgaris L. Plant Signal. Behav. 2021, 16, 1853384. [CrossRef]

16. Jabborova, D.; Wirth, S.; Kannepalli, A.; Narimanov, A.; Desouky, S.; Davranov, K.; Sayyed, R.Z.; Enshasy, H.; AbdMalek, R.; Syed, A.; et al. Co-inoculation of rhizobacteria and biochar application improves growth and nutrientsin soybean and enriches soil nutrients and enzymes. Agronomy 2020, 10, 1142. [CrossRef]

17. Rondon, M.A.; Lehmann, J.; Ramírez, J.; Hurtado, M. Biological nitrogen fixation by common beans (Phaseolus vulgaris L.) increases with bio-char additions. Biol. Fertil. Soils 2007, 43, 699-708. [CrossRef]

18. Chan, K.Y.; Xu, Z. Biochar: Nutrient Properties and Their Enhancement. In Biochar for Environmental Management; Lehmann, J., Joseph, S.D., Eds.; Routledge: Oxfordshire, UK, 2009; pp. 99-116.

19. Gaskin, J.W.; Speir, R.A.; Harris, K.; Das, K.C.; Lee, R.D.; Morris, L.A.; Fisher, D.S. Effect of peanut hull and pine chip biochar on soil nutrients, corn nutrient status, and yield. Agron. J. 2010, 102, 623-633. [CrossRef]

20. Lehmann, J.; Rillig, M.C.; Thies, J.; Masiello, C.A.; Hockaday, W.C.; Crowley, D. Biochar effects on soil biota-A review. Soil Biol. Biochem. 2011, 43, 1812-1836. [CrossRef]

21. Saxena, J.; Rana, G.; Pandey, M.J. Impact of addition of biochar along with Bacillus sp. on growth and yield of French beans. Sci. Hortic. 2013, 162, 351-356. [CrossRef] 
22. Carter, S.; Shackley, S.; Sohi, S.; Suy, T.B.; Haefele, S. The impact of biochar application on soil properties and plant growth of pot grown lettuce (Lactuca sativa) and cabbage (Brassica chinensis). Agronomy 2013, 3, 404-418. [CrossRef]

23. Agegnehu, G.; Bass, A.M.; Nelson, P.N.; Muirhead, B.; Wright, G.; Bird, M.I. Biochar and biochar-compost as soil amendments: Effects on peanut yield, soil properties and greenhouse gas emissions in tropical North Queensland, Australia. Agric. Ecosyst. Environ. 2015, 213, 72-85. [CrossRef]

24. Jeffery, S.; Abalos, D.; Prodana, M.; Bastos, A.; van Groenigen, J.W.; Hungate, B.; Verheijen, F. Biochar boosts tropical but not temperate crop yields. Environ. Res. Lett. 2017, 12, 053001. [CrossRef]

25. Zhang, H.; Voroney, R.; Price, G. Effects of temperature and processing conditions on biochar chemical properties and their influence on soil C and N transformations. Soil Biol. Biochem. 2015, 83, 19-28. [CrossRef]

26. Jabborova, D.; Wirth, S.; Halwani, M.; Ibrahim, M.F.; Azab, I.H.E.; El-Mogy, M.M.; Elkelish, A. Growth response of ginger (Zingiber officinale), its physiological properties and soil enzyme activities after biochar application under greenhouse conditions. Horticulturae 2021, 7, 250. [CrossRef]

27. Jabborova, D.; Ma, H.; Bellingrath-Kimura, S.D.; Wirth, S. Impacts of biochar on basil (Ocimum basilicum) growth, root morphological traits, plant biochemical and physiological properties and soil enzymatic activities. Sci. Hortic. 2021, $290,110518$. [CrossRef]

28. Jabborova, D.; Annapurna, K.; Al-Sadi, A.M.; Alharbi, S.A.; Datta, R.; Zuan, A.T.K. Biochar and Arbuscular mycorrhizal fungi mediated enhanced drought tolerance in Okra (Abelmoschus esculentus) plant growth, root morphological traits and physiological properties. Saudi J. Biol. Sci. 2021, 28, 5490-5499. [CrossRef]

29. Jabborova, D.; Annapurna, K.; Paul, S.; Kumar, S.; Saad, H.A.; Desouky, S.; Elkelish, A. Beneficial features of biochar and arbuscular mycorrhiza for improving spinach plant growth root morphological traits, physiological properties, and soil enzymatic activities. J. Fungi 2021, 7, 571. [CrossRef]

30. He, X.; Xie, H.; Gao, D.; Rahman, K.U.; Zhou, X.; Wu, F. Biochar and intercropping with potato-onion enhanced the growth and yield advantages of tomato by regulating the soil properties, nutrient uptake, and soil microbial community. Front. Microbiol. 2021, 2334. [CrossRef]

31. Wang, Y.; Yin, R.; Liu, R. Characterization of biochar from fast pyrolysis and its effect on chemical properties of the tea garden soil. J. Anal. Appl. Pyrol. 2014, 110, 375-381. [CrossRef]

32. Major, J.; Rondon, M.; Molina, D.; Riha, S.J.; Lehmann, J. Maize yield and nutrition during 4 years after biochar application to a Colombian savanna oxisol. Plant Soil 2010, 333, 117-128. [CrossRef]

33. Anderson, C.R.; Condron, L.M.; Clough, T.J. Biochar induced soil microbial community change: Implications for biogeochemical cycling of carbon, nitrogen and phosphorus. Pedobiologia 2011, 54, 309-320. [CrossRef]

34. Trupiano, D.; Cocozza, C.; Baronti, C.; Amendola, C.; Vaccari, F.P.; Lustrato, G.; Lonardo, S.D.; Fantasma, F.; Tognetti, R.; Scippa, G.S. The effects of biochar and its combination with compost on lettuce (Lactuca sativa L.) growth, soil properties, and soil microbial activity and abundance. Int. J. Agron. 2017, 10, 12.

35. Subhani, A.; Changyong, H.; Zhengmiao, Y.; Min, L.; El-ghamry, A. Impact of soil environment and agronomic practices on microbial dehydrogenase enzyme activity in soil. Pak. J. Biol. Sci. 2001, 4, 333-338. [CrossRef]

36. Oguntunde, P.; Fosu, M.; Ajayi, A.; Giesen, N. Effects of charcoal production on maize yield, chemical properties and texture of soil. Biol. Fertil. Soils 2004, 39, 295-299. [CrossRef]

37. Głodowska, M.; Schwinghamer, T.; Husk, B.; Smith, D. Biochar based inoculants improve soybean growth and nodulation. Agric. Sci. 2017, 8, 1048-1064. [CrossRef]

38. Sarma, B.; Borkotoki, B.; Narzari, R.; Kataki, R.; Gogoi, N. Organic amendments: Effect on carbon mineralization and crop productivity in acidic soil. J. Clean. Prod. 2017, 152, 157-166. [CrossRef]

39. Ma, H.; Egamberdieva, D.; Wirth, S.; Bellingrath-Kimura, S.D. Effect of biochar and irrigation on soybean-Rhizobium symbiotic performance and soil enzymatic activity in field rhizosphere. Agronomy 2019, 9, 626. [CrossRef]

40. Qayyum, M.F.; Haider, G.; Raza, M.A.; Abdel Kareem, S.H.; Mohamed, A.K.S.N.; Rizwan, M.; El-Sheikh, M.A.; Alyemeni, M.N.; Ali, S. Straw-based biochar mediated potassium availability and increased growth and yield of cotton (Gossypium hirsutum L.). J. Saudi Chem. Soc. 2020, 10, 1016. [CrossRef]

41. Wu, Z.; Li, H.; Liu, Q.; Ye, C.; Yu, F. Application of bio-organic fertilizer, not biochar, in degraded red soil improves soil nutrients and plant growth. Rhizosphere 2020, 16, 100264.

42. Speratti, A.B.; Johnson, M.S.; Sousa, H.M.; Dalmagro, H.J.; Couto, E.G. Biochars from local agricultural waste residues contribute to soil quality and plant growth in a Cerrado region (Brazil) Arenosol. GCB Bioenergy 2018, 10, 272-286. [CrossRef]

43. Clark, R.B.; Zeto, S.K. Growth and root colonization of mycorrhizal maize grown on acid and alkaline soil. Soil Biol. Biochem. 1996, 28, 1505-1511. [CrossRef]

44. Meding, S.M.; Zasoski, R.J. Hyphal-mediated transfer of nitrate, arsenic, cesium, rubidium, and strontium between arbuscular mycorrhizal forbs and grasses from a California oak woodland. Soil Biol. Biochem. 2008, 40, 126-134. [CrossRef]

45. Javaid, A. Arbuscular mycorrhizal mediated nutrition in plants. J. Plant Nutr. 2009, 32, 1595-1618. [CrossRef]

46. Abdel Latef, A.A. Influence of arbuscular mycorrhizal fungi and copper on growth, accumulation of osmolyte, mineral nutrition and antioxidant enzyme activity of pepper (Capsicum annuum L.). Mycorrhiza 2011, 21, 495-503. [CrossRef] [PubMed]

47. Abdel Latef, A.A.; Chaoxing, H. Arbuscular mycorrhizal influence on growth, photosynthetic pigments, osmotic adjustment and oxidative stress in tomato plants subjected to low temperature stress. Acta Physiol. Plant. 2011, 33, 1217-1225. [CrossRef] 
48. Cavagnaro, T.R.; Jackson, L.E.; Six, J.; Ferris, H.; Goyal, S.; Asami, D. Arbuscular mycorrhizas, microbial communities, nutrient availability, and soil aggregates in organic tomato production. Plant Soil 2006, 282, 209-225. [CrossRef]

49. Nunes, J.L.D.; de Souza, P.V.D.; Marodin, G.A.B.; Fachinello, J.C. Effect of arbuscular mycorrhizal fungi and indole butyric acid interaction on vegetative growth of Aldrighi peach rootstock seedlings. Cienc. Agrotecnol. 2010, 34, 80-86. [CrossRef]

50. Alizadeh, O.; Zare, M.; Nasr, A.H. Evaluation effect of Mycorrhiza inoculate under drought stress condition on grain yield of sorghum (Sorghum bicolor). Adv. Environ. Biol. 2011, 5, 2361-2364.

51. Yaseen, T.; Burni, T.; Hussain, F. Effect of arbuscular mycorrhizal inoculation on nutrient up- take, growth and productivity of chickpea (Cicer arietinum) varieties. Int. J. Agron. Plant Prod. 2012, 3, 334-345.

52. Shokri, S.; Maadi, B. Effects of arbuscular mycorrhizal fungus on the mineral nutrition and yield of Trifolium alexandrinum plants under salinity stress. J. Agron. 2000, 8, 79-83. [CrossRef]

53. Najafi, A.; Ardakani, M.R.; Rejali, F.; Sajedi, N. Response of winter barley to co-inoculation with Azotobacter and Mycorrhiza fungi influenced by plant growth promoting rhizobacteria. Ann. Biol. Res. 2012, 3, 4002-4006.

54. El Seoud, A. Effect of biochar rates on Amycorrhizal fungi performance and maize plant growth, Phosphorus uptake, and soil $\mathrm{P}$ availability under calcareous soil conditions. Commun. Soil Sci. Plant Anal. 2021, 52, 815-831.

55. Chiomento, J.L.T.; de Nardi, F.S.; Filippi, D.; dos Santos, T.T.; Dornelles, A.G.; Fornari, M.; Calvete, E.O. Morpho-horticultural performance of strawberry cultivated on substrate with arbuscular mycorrhizal fungi and biochar. Sci. Hortic. 2021, $282,110053$. [CrossRef]

56. Liang, J.F.; An, J.; Gao, J.Q.; Zhang, X.Y.; Song, M.H.; Yu, F.H. Interactive effects of biochar and AMF on plant growth and greenhouse gas emissions from wetland microcosms. Geoderma 2019, 346, 11-17. [CrossRef]

57. Barrs, H.D.; Weatherley, P.E. A re-examination of the relative turgidity technique for estimating water deficit in leaves. Aust. J. Biol. Sci. 1962, 15, 413-428. [CrossRef]

58. Hiscox, J.D.; Israelstam, G.F. A method for the extraction of chlorophyll from leaf tissue without maceration. Can. J. Bot. 1979, 57, 1332-1334. [CrossRef]

59. Dare, M.O.; Abaidoo, R.; Fagbola, O.; Asideu, R. Diversity of AMF in soils of yam (Diosocera spp.) cropping systems in four agroecologies of Nigeria. Achieves Agron. Soil Sci. 2013, 59, 521-531. [CrossRef]

60. Vance, E.D.; Brookes, P.C.; Jenkinson, D.S. An extraction method for measuring soil microbial biomass C. Soil Biol. Biochem. 1987, 19, 703-707. [CrossRef]

61. Tabatabai, M.A.; Bremner, J.M. Use of p-nitrophenol phosphate for the assay of soil phosphatase activity. Soil Biol. Biochem. 1969, 1,301-307. [CrossRef]

62. Green, V.S.; Stott, D.E.; Diack, M. Assay for fluorescein diacetate hydrolytic activity: Optimization for soil samples. Soil Biol. Biochem. 2006, 38, 693-701. [CrossRef]

63. Casida, L.E.; Klein, D.A.; Santoro, T. Soil dehydrogenase activity. Soil Sci. 1964, 98, 371-376. [CrossRef]

64. Zheng, R.; Li, C.; Sun, G.; Xie, Z.; Chen, J.; Wu, J.; Wang, Q. The influence of particle size and feedstock of biochar on the accumulation of $\mathrm{Cd}, \mathrm{Zn}, \mathrm{Pb}$, and As by Brassica chinensis L. Environ. Sci. Pollut. Res. 2017, 24, 22340-22352. [CrossRef]

65. Gonzaga, M.I.; Mackowiak, C.; de Almeida, A.Q.; de Carvalho Junior, J.I.; Andrade, K.R. Positive and negative effects of biochar from coconut husks, orange bagasse and pine wood chips on maize (Zea mays L.) growth and nutrition. Catena 2018, 162, 414-420. [CrossRef]

66. Bopp, C.; Christl, I.; Schulin, R.; Evangelou, M.W. Biochar as possible long-term soil amendment for phytostabilisation of TE-contaminated soils. Environ. Sci. Pollut. Res. 2016, 17, 17449-17458. [CrossRef]

67. Gamalero, E.; Trotta, A.; Massa, N.; Copetta, A.; Martinotti, M.G.; Berta, G. Impact of two fluorescent pseudomonads and an arbuscular mycorrhizal fungus on tomato plant growth, root architecture and Pacquisition. Mycorrhiza 2003, 14, 185-192. [CrossRef] [PubMed]

68. Singh, S.; Pandey, A.; Kumar, B.; Palni, L.M.S. Enhancement in growth and quality parameters of tea [Camellia sinensis (L.) O. Kuntze] through inoculation with arbuscular mycorrhizal fungi in an acid soil. Biol. Fertil. Soils 2010, 46, 427-433. [CrossRef]

69. Gogoi, P.; Singh, R.K. Differential effect of some arbuscular mycorrhizal fungi on growth of Piper longum L. (Piperaceae). Indian J. Sci. Technol. 2011, 4, 119-125. [CrossRef]

70. Ortas, I.; Ustuner, O. The effects of single species, dual species and indigenous mycorrhiza inoculation on citrus growth and nutrient uptake. Eur. J. Soil Biol. 2014, 63, 64-69. [CrossRef]

71. Nakmee, P.S.; Techapinyawat, S.; Ngamprasit, S. Comparative potentials of native arbuscular mycorrhizal fungi to improve nutrient uptake and biomass of Sorghum bicolor Linn. Agric. Nat. Resour. 2016, 50, 173-178. [CrossRef]

72. Bona, E.; Cantamessa, S.; Massa, N.; Manassero, P.; Marsano, F.; Copetta, A.; Lingua, G.; D'Agostino, G.; Gamalero, E.; Berta, G. Arbuscular mycorrhizal fungi and plant growth-promoting pseudomonads improve yield, quality and nutritional value of tomato: A field study. Mycorrhiza 2016, 27, 1-11. [CrossRef]

73. Parihar, P.; Bora, M. Effect of mycorrhiza (Glomus mosseae) on morphological and biochemical properties of Ashwagandha (Withania somnifera) (L.) Dunal. J. Appl. Nat. Sci. 2018, 10, 1115-1123. [CrossRef]

74. Fougnies, L.; Renciot, S.; Müller, F.; Plenchette, C.; Prin, Y.; de Faria, S.M.; Bouvet, J.M.; Sylla, S.N.; Dreyfus, B.; Bâ, A.M. Arbuscular mycorrhizal colonization and nodulation improve flooding tolerance in Pterocarpus officinalis Jacq. seedlings. Mycorrhiza 2006, 17, 159-166. [CrossRef] 
75. Sharma, D.; Kayang, H. Effects of arbuscular mycorrhizal fungi (AMF) on Camellia sinensis (L.) O. Kuntze under greenhouse conditions. J. Exp. Biol. 2017, 5, 235-241. [CrossRef]

76. Budi, S.W.; Setyaningsih, L. Arbuscular mycorrhizal fungi and biochar improved early growth of neem (Melia azedarach Linn.) seedling under greenhouse conditions. J. Manaj. Hutan Trop. 2013, 2, 103-110.

77. Li, M.; Cai, L. Biochar and Arbuscular Mycorrhizal fungi play different roles in enabling maize to uptake phosphorus. Sustainability 2021, 13, 3244. [CrossRef]

78. Uzoma, K.; Inoue, M.; Andry, H.; Fujimaki, H.; Zahoor, A.; Nishihara, E. Effect of cow manure biochar on maize productivity under sandy soil condition. Soil Use Manag. 2011, 27, 205-212. [CrossRef]

79. Ameloot, N.; Sleutel, S.; Case, S.D.C.; Alberti, G.; McNamara, N.P.; Zavalloni, C.; Vervisch, B.; delle Vedove, G.; de Neve, S. C mineralization and microbial activity in four biochar field experiments several years after incorporation. Soil Biol. Biochem. 2014, 78, 195-203. [CrossRef]

80. Gul, S.; Whalen, J.K. Biochemical cycling of nitrogen and phosphorus in biochar-amended soils. Soil Biol. Biochem. 2016, 103, 1-15. [CrossRef]

81. Butnan, S.; Deenik, J.L.; Toomsan, B.; Antal, M.J.; Vityakon, P. Biochar characteristics and application rates affecting corn growth and properties of soils contrasting in texture and mineralogy. Geoderma 2015, 237, 105-116. [CrossRef]

82. Bu, X.; Xue, J.; Wu, Y.; Ma, W. Effect of Biochar on Seed Germination and Seedling Growth of Robinia pseudoacacia L. In Karst Calcareous Soils. Commun. Soil Sci. Plant Anal. 2020, 10, 1080. [CrossRef]

83. Zhang, L.; Xu, M.; Liu, Y.; Zhang, F.; Hodge, A.; Feng, G. Carbon and phosphorus exchange may enable cooperation between an arbuscular mycorrhizal fungus and a phosphate-solubilizing bacterium. New Phytol. 2016, 210, 1022-1032. [CrossRef] [PubMed]

84. Berta, G.; Sampo, S.; Gamalero, E.; Massa, N.; Lemanceau, P. Suppression of Rhizoctonia root-rot of tomato by Glomus mossae BEG12 and Pseudomonas fluorescens A6RI is associated with their effect on the pathogen growth and on the root morphogenesis. Eur. J. Plant Pathol. 2005, 111, 279-288. [CrossRef]

85. Maherali, H. Is there an association between root architecture and mycorrhizal growth response? New Phytol. 2014, 204, 192-200. [CrossRef]

86. Kim, S.J.; Eo, J.-K.; Lee, E.-H.; Park, H.; Eom, A.-H. Effects of arbuscular mycorrhizal fungi and soil conditions on crop plant growth. Mycobiology 2017, 45, 20-24. [CrossRef]

87. Cosme, M.; Wurst, S. Interactions between arbuscular mycorrhizal fungi, rhizobacteria, soil phosphorus and plant cytokinin deficiency change the root morphology, yield and quality of tobacco. Soil Biol. Biochem. 2013, 57, 436-443. [CrossRef]

88. Hashem, A.; Kumar, A.; Al-Dbass, A.M.; Alqarawi, A.A.; Al-Arjani, A.B.; Singh, G.; Farooq, M.; Abd Allah, E.F. Arbuscular mycorrhizal fungi and biochar improves drought tolerance in chickpea. Saudi J. Biol. Sci. 2019, 26, 614-624. [CrossRef] [PubMed]

89. Bi, Y.; Zhang, J.; Song, Z.; Wang, Z.; Qiu, L.; Hu, J.; Gong, Y. Arbuscular mycorrhizal fungi alleviate root damage stress induced by simulated coal mining subsidence ground fissures. Sci. Total Environ. 2019, 652, 398-405. [CrossRef]

90. Padmavathi, T.; Dikshit, R.; Seshagiri, S. Influence of Rhizophagus spp. and Burkholderi aseminalis in the growth of tomato (Lycopersicon esculatum) and bell pepper (Capsicum annuum) under drought stress. Commun. Soil Sci. Plant Anal. 2016, 47, 1975-1984.

91. Petruccelli, R.; Bonetti, A.; Traversi, M.L.; Faraloni, C.; Valagussa, M.; Pozz, A. Influence of biochar application on nutritional quality of tomato (Lycopersicon esculentum). Crop. Pasture Sci. 2015, 10, 1071. [CrossRef]

92. He, Y.; Yao, Y.; Ji, Y.; Deng, J.; Zhou, G.; Liu, R.; Shao, J.; Zhou, L.L.N.; Zhou, X.; Bai, S.H. Biochar amendment boosts photosynthesis and biomass in C3 but not C4 plants: A global synthesis. GCB Bioenergy 2020, 12, 605-617. [CrossRef]

93. Dell'Amico, J.; Torrecillas, A.; Rodríguez, P.; Morte, A.; Sánchez-Blanco, M.J. Responses of tomato plants associated with the arbuscular mycorrhizal fungus Glomus clarum during drought and recovery. J. Agric. Sci. 2002, 138, 387-393. [CrossRef]

94. Ren, A.T.; Zhu, Y.; Chen, Y.L.; Ren, H.X.; Li, J.Y.; Kay Abbott, L.; Xiong, Y.C. Arbuscular mycorrhizal fungus alters root-sourced signal (abscisic acid) for better drought acclimation in Zea mays L. seedlings. Environ. Exp. Bot. 2019, 167, 103824. [CrossRef]

95. Solaiman, Z.M.; Blackwell, P.; Abbott, L.K.; Storer, P. Direct and residual effect of biochar application on mycorrhizal root colonisation, growth and nutrition of wheat. J. Soil Res. 2010, 48, 546-554. [CrossRef]

96. Vanek, S.J.; Lehmann, J. Phosphorus availability to beans via interactions between mycorrhizas and biochar. Plant Soil 2015, 395, 105-123. [CrossRef]

97. Mickan, B.S.; Abbott, L.K.; Stefanova, K.; Solaiman, Z.M. Interactions between biochar and mycorrhizal fungi in a water-stressed agricultural soil. Mycorrhiza 2016, 26, 565-574. [CrossRef] [PubMed]

98. Ouyang, L.; Tang, Q.; Yu, L.; Zhang, R. Effects of amendment of different biochars on soil enzyme activities related to carbon mineralisation. Soil Res. 2014, 52, 706-716. [CrossRef]

99. Wang, L.; Xue, C.; Nie, X.; Liu, Y.; Chen, F. Effects of biochar application on soil potassium dynamics and crop uptake. J. Plant Nutr. Soil Sci. 2018, 181, 635-643. [CrossRef]

100. Oladele, S.O. Effect of biochar amendment on soil enzymatic activities, carboxylate secretions and upland rice performance in a sandy clay loam Alfisol of Southwest Nigeria. Sci. Afr. 2019, 4, e00107. [CrossRef]

101. Bailey, V.L.; Fansler, S.J.; Smith, J.L.; Bolton, H., Jr. Reconciling apparent variability in effects of biochar amendment on soil enzyme activities by assay optimization. Soil Biol. Biochem. 2011, 43, 296-301. [CrossRef]

102. Günal, E.; Erdem, H.; Demirbaş, A. Effects of three biochar types on activity of $\beta$-glucosidase enzyme in two agricultural soils of different textures. Arch. Agron. Soil Sci. 2018, 64, 1963-1974. [CrossRef] 
103. Masto, R.E.; Kumar, S.; Rout, T.K.; Sarkar, P.; George, J.; Ram, L.C. Biochar from water hyacinth (Eichornia crassipes) and its impact on soil biological activity. Catena 2013, 111, 64-71. [CrossRef]

104. Ziheng, S.; Yinli, B.; Zhang, J.; Yunli, G.; Yang, H. Arbuscular mycorrhizal fungi promote the growth of plants in the mining associated clay. Sci. Rep. 2020, 10, 2663. 